\title{
CORONAVIRUS VS. REAL CAUSE OF THE EUROPEAN ECONOMIC CRISIS - COMPARING SLOVAK AND GERMAN NATIONAL MODEL EXAMPLE
}

\author{
Peter ADAMIŠIN, PhD \\ Prešov University, Faculty of Management, Prešov, Slovakia \\ peter.adamisin@unipo.sk
}

Ivana BUTORACOVÁ ŠINDLERYOVÁ, PhD

University of Ss. Cyril and Methodius, Faculty of Social Sciences, Trnava, Slovakia

ivana.butoracova@ucm.sk

Andrea ČAJKOVÁ, PhD

University of Ss. Cyril and Methodius, Faculty of Social Sciences, Trnava, Slovakia

andrea.cajkova@ucm.sk

\begin{abstract}
The main purpose of this study is to present possible causes of the economic crisis in most European countries considering not only the coronavirus, but mainly the development of economic indicators such as wages and labour productivity in the period of 2000-2019. The authors try to prove, that the economic crisis was clearly predictable in the Slovak Republic (and many other European countries) despite the whole coronavirus issue, and they identify the spectrum of the correlation of these developmental features and predictors, but also point out that the interconnection of the analysed issues cannot always represent direct dependence on the long-term sustainable growth of the economy. The authors focus on the question of the possible sustainability of wage development in the Slovak Republic based on the analysis of the relevant determinants as well as in comparison with the oftendiscussed German European example. Comparing the development level and wages structure in the period before and after the national accession into the EMU, the authors try to warn about the resulting problem of the country's economy in connection with the current unsustainability of the growth of wages and labour productivity, which in final was not caused, just accelerated by both government and economic limitations related to coronavirus issue.
\end{abstract}

Keywords: Wages, analysis, Labour productivity, Comparison, Progress, Sustainability, Pandemic crisis. 


\section{Introduction and Literature Review}

The labour market is one of the crucial markets for the efficient functioning of the economy. For households as well as individuals, the market is not only an opportunity to earn money for retirement but also a place to meet non-economic needs such as self-fulfilment, social status, etc. For businesses, the market presents an appropriate place to implement their internal transformation processes (Charaia et al. 2020; Vacok et al., 2020). For the state, the market is significant not only a source of income, but also an important instrument for the implementation of its economic policy. The importance of the labour market is highlighted by some other basic economic contexts. The fact is that in the economy as a whole the labour market is a transfer mechanism between production and consumption processes (Lim 2017). However, as in other markets, it is highly desirable to achieve and sustainably maintain the expected balance so that the aggregate work offer equals to aggregate demand for work.

The economy operates in full employment and in equilibrium with real wages only if the market balance is provided (e.g. Peráček, 2021). Therefore, we might come to a conclusion that the balance in the labour market is strongly determined by the national wage growth. This market balance is affected by three main factors which are the economic prosperity (closely dependant on the increase in labour productivity), wages allocation and labour force adaptability. The authors national and worldwide (Fehr \& Goette 2005; Balcar \& Gottvald 2016; Goerree and Lindsay 2016; Dudic et al. 2020; Novosák et al. 2017; etc.) claim that an important role in the market is played by the state itself as a specific market subject by being responsible for a system of interventions that can lead to a "deviation” from equilibrium (by implementation of the direct or indirect actions in order to regulate the workforce. As Hajduová et al. (2021) states, the labour market is rigid, which is due to inflexible prices. Considering the longer period of time, wage rates present an upward trend in the Slovak economy (Kováčiková \& Jančovičová, 2017). We take into account the comparison of the Hungarian model and the French one, where the statistical analysis indicates a rapid growth in individual wage inequalities in Hungary unlike in France (Chochia \& Kerikmäe, 2018). In the former country, the development of small, private firms paying relatively low wages in contrast with foreign owned firms explains part of this phenomenon (Szeiner et al. 2020; Srebalová \& Vojtech, 2021). 
A high level of labour market institutionalization leads to an uncompetitive market environment, the absence of information about both the supply and the demand for the labour market actors as well as their incompleteness usually leads to irrational market decisions and globally causes the market imperfections (Lubyová \& Štefánik 2017; Rusnák 2016). According to Žofčinová \& Hrabovská, (2019) the rigidity of the labour market is also caused by the heterogeneity of the job offer leading to the mutual incompetence of the professions, without the possibility of mutual substitution. Research on the wages development in the Slovak Republic has been very intensive since the fall of the communism in 1989, as well as in other east European countries, however, we might argue about its relevance and the significance of the presented data. Based on various sources, including national databases and official websites administered by various economic institutions, great attention was paid to the examination of factors influencing the wages development as well as the investigation of the relation of wages to the development of labour productivity (Kajanová et al., 2018). Labour productivity is a key factor in the competitiveness and economic performance of the national economies.

The potential growth in the productivity is particularly important at a time of declining demographic trend that is plaguing the whole European Union. (Čajka \& Abrhám, 2019; Novackova \& Peracek, 2021). Taking into account the immigration, this is a potential way of replacing the declining workforce. According to various national and worldwide authors (e.g. Martino, 2015; Gault 2018; Terem et al. 2015; Psychogios et al. 2019), the key factors influencing the labour productivity growth include: education, research and development, modern technological solutions of production, digital technologies, working conditions and motivation of employees. Basically, the Solow-Swan growth model (Mucha et al., 2018) is often seen as a building block among various growth-economic theories, though it is not an ideal model to predict behaviour, though it provides a researcher with a useful insight what might be causing growth.

Due to the paper size limitation, the authors briefly present the related literature sources as the main objective of the study is to present the empirical data gained in the research in order to verify the continuity and progress of the wage development in relation to labour productivity, considering the international diversification (Wefersová et al., 2021). The paper is divided into three main parts, including the research methodology description, the analysis description and the summary of the results leading to a constructive discussion followed by relevant and current conclusions. 


\section{Methodology and Research}

The macroeconomic data on wages and labour productivity available at public sources and websites of statistical organizations were used for the analytical research (Statistical Office of the Slovak Republic, Statdat, OECD, EUROSTAT, IMF, WB, etc.). For international comparisons, OECD data (datasets) available at http://stats.oecd.org/ were used. All the average annual wages from the period of 2000 to 2019 are set in current prices, the data from the period of 1999 till 2018 were analysed what represents adjusted data from the period of 2000-2019. Data for international labour productivity comparison were obtained from www.oecd.org/std/productivity-stats, representing labour productivity growth based on hours worked for 2000-2019 and expressed as average annual growth rates in percentage points. Data related to wage indicators were converted to the same unit as the labour productivity, i.e. to average annual growth rates in percentage points. The analysed period covered the years 2000-2019. GDP and productivity are the main indicators of the national economies competitiveness. Including the inflation ratio, the productivity expresses the basis in the prediction of wages development progress. The average wages are therefore based on the nominal monthly wages. National comparisons were based on monthly statistical reports, with the following analysed parameters:

- average nominal monthly wage of an employee by economic activity (SK NACE Rev. 2) in EUR,

- labour productivity from revenues for own goods and services by economic activity (OKEC) in EUR, index in the period of 2000-2007,

- labour productivity from revenues for own outputs and goods by category and special groupings of industries in the classification of economic activities (SK NACE Rev. 2) in EUR, index in the period of 2008-2019,

- labour productivity per employee was based on current prices.

Data gained for the comparison at national level were processed on the basis of the Statistical Office of the Slovak Republic. Several partial methods of statistical analysis, including the concept of research methodology of other authors in the field (Šubová et al., 2021; Kajanova et al. 2018; Mucha et al. 2018; Giannone et al. 2008; Rusnak 2016; etc.) were used. For choosing appropriate tests of correlation analysis, the testing of the normal distribution of sample files was 
used. The authors applied a Kolmogorov-Smirnov test to verify normality. The KolmogorovSmirnov test formula is defined as

$$
D=\max _{1 \leq i \leq N}\left(F\left(Y_{i}\right)-\frac{i-1}{N}, \frac{i}{N}-F\left(Y_{i}\right)\right)
$$

where:

$\mathrm{F}$ is the theoretical cumulative distribution of the distribution being tested which must be a continuous distribution, and it must be fully specified.

The Kolmogorov-Smirnov test is defined by:

H0: The data follow a specified distribution.

H1: The data do not follow the specified distribution.

The hypothesis regarding the distributional form is rejected if the test statistic, D, is greater than the critical value obtained from a table (https://www.itl.nist.gov).

We used the SPSS and NCSS statistical software environment for all partial analyses, the outputs of which authorized us to accept or reject the zero hypothesis about the normality of the distribution. This testing was a necessary basis for the methodological acceptance of the parametric tests. The analysis of the context of quantitative phenomena (between wage height and labour productivity) was realized through the Pearson's correlation coefficient.

$\rho_{X_{x} Y}=\frac{\operatorname{cov}(\mathbf{X}, \mathbf{Y})}{\sigma_{X} \sigma_{Y}}$

where:

cov is the covariance,

$\square \mathrm{X}$ is the standard deviation of $\mathrm{X}$,

$\square \mathrm{Y}$ is the standard deviation of $\mathrm{X}$,

and

$\operatorname{cov}(\mathrm{X}, \mathrm{Y})=\mathrm{E}[(\mathrm{X}-\square \mathrm{X})(\mathrm{Y}-\square \mathrm{Y})]$,

where:

$\square \mathrm{X}$ is the mean of $\mathrm{X}$,

$\square \mathrm{Y}$ is the mean of $\mathrm{Y}$, 
E is the expectation, where we observed the statistical proof of the relationship (expressed by the p-value) and the tightness of the relations (expressed by the value of the correlation coefficient). We also monitored the dynamics of changes in selected parameters in two periods before and after entering the EMU to identify the impact of the change on the potential statistical evidence of the difference in dynamics of the observed parameters development (specifically for labour productivity and specifically for wages). We applied the Independent Samples Test after testing the Leven test for scattering. The Leven test testing is defined as:

$W=\frac{(N-k)}{(k-1)} \sum_{i=1}^{k} \frac{N_{i}\left(Z_{i}-Z_{-}\right)^{2}}{\sum_{i=1}^{k} \sum_{j=1}^{N_{i}}\left(Z_{i j}-Z_{i .}\right)^{2}}$

where:

$\mathrm{k}$ is the number of different groups to which the sampled cases belong,

$\mathrm{Ni}$ is the number of cases in the i-th group,

$\mathrm{N}$ is the total number of cases in all groups,

Yij is the value of the measured variable for the $\mathrm{j}$-th case from the $\mathrm{i}$-th group,

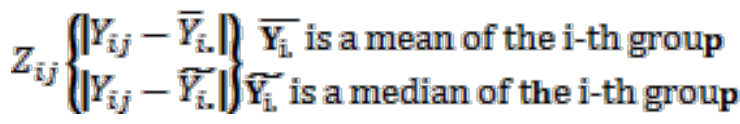

$Z_{i .}=\frac{\mathbf{1}}{N_{i}} \sum_{j=\mathbf{1}}^{N_{i}} Z_{i j}$

is the mean of the $\mathrm{Zij}$ for group I,

$Z_{-}=\frac{1}{N_{i}} \sum_{i=1}^{k} \sum_{j=1}^{N_{i}} Z_{i j}$

is the mean of all $\mathrm{Zij}$.

The test results for acceptance of the mean values of the two-period sets were based on the p-value of the respective test. The change of the overall indicator in time with the modelling of the possible future development, ceteris paribus, was performed by regression analysis. If the regression model quality (measured by parameters R2, F-value, p-value) was statistically proved, we would choose the linear regression model $\mathrm{y}=\mathrm{b}_{0}+\mathrm{b}_{1} \mathrm{x}$ for simplicity of interpretation. 
2.1 Analysis of wages development in the Slovak Republic in the period of $2000-2019$ (compared to Germany)

The authors do not interpret the wages as a cash payment that the employer is obliged to provide to employees by the law, but they focus on the systematic terminological understanding in the context of the average wage as a statistical indicator calculated by the arithmetic mean of all gross wages of the selected group of individuals, mostly full-time job employees. The searched wage development period is defined by the fall of the Communist regime in 1989 and reconstruction of the national economy in the next decade, with indicated changes and processes being investigated over the period to date. Wage developments in the national economy is described in the figure below; it is clear that the average nominal wage in the national economy shows an annual increase.

Fig. 1 Average nominal monthly wage of an employee in the Slovak Republic in $€$

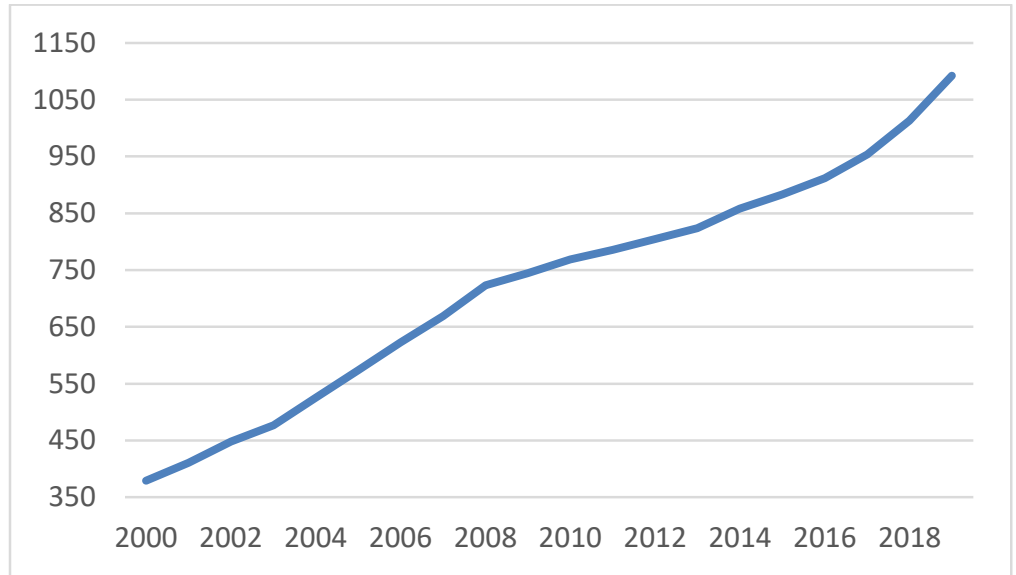

Source: Own processing based on the data of The Statistical Office of the Slovak Republic.

Continuously, we estimated the wages development in the reference period by the regression model. By linear regression modelling of the development of the nominal wages from the period of 2000-2019, we analysed the average interannual change in wages. In this case, it is the interannual increase in wages by $€ 34.453$ (Table 1). The model itself as well as the partial parameters results are statistically significant. 
Tab. 1 Regression analysis, modelling of wages development in the Slovak Republic in the period of 2000-2019

\begin{tabular}{|c|c|c|c|c|c|}
\hline \multirow[b]{2}{*}{ Model } & \multicolumn{2}{|c|}{ Unstandardized Coefficients } & \multirow{2}{*}{$\begin{array}{c}\text { Standardized } \\
\text { Coefficients } \\
\text { Beta }\end{array}$} & \multirow[b]{2}{*}{$\mathrm{T}$} & \multirow[b]{2}{*}{ Sig. } \\
\hline & B & Std. Error & & & \\
\hline 1 (Constant) & 361.685 & 12.698 & & 28.484 & .000 \\
\hline Year & 34.453 & 1.060 & 992 & 32.504 & .000 \\
\hline
\end{tabular}

Notes: a. Dependent Variable: avg_wage; based on the formula: $\mathrm{y}^{++}=361.685^{++}+34.453^{++} \mathrm{x}$.

Source: Authors' calculation based on the analysed data.

Thus, the legitimate question arises: was this trend sustainable? Was this trend in correlation with rising labour productivity? Of course, from the employee's point of view, it is possible to speak of a definitely positive trend, the position of the employer is already unambiguous even if it is not necessary, especially in terms of growth of wages in relation to the growth or decline in labour productivity. In the context of the continuous increase in wages, it is necessary to be aware of the disparities that characterize the Slovak region in comparison with Europe (Vilčeková et al. 2020; Mihálik et al., 2019). The authors (Balčár \& Gottvald, 2016) claim that statistically significant changes in return to particular wage determinants were limited during the crisis in the period 2008-2014. For example, investigation the trade-off between wage and workforce adjustments and the role of industrial relations in firm-level responses to the economic crisis in Germany and the Netherlands offer Tijdens et al. (2014) in their study. The crisis affected mainly the wages demand determinants.

The time inconsistency phenomenon in the national economic policy implementation has been analysed by many authors and leads to a concrete foundation that the discretionary wages policy approach with the possibility of everyday change leads to worse macroeconomic results in the long run though performing a positive result in the current period of time (Sinikáčová \& Gavurová, 2017). The wage disparities present a general problem. Comparing average wages in the Slovak economy and for example in Germany, as one of the most important business partners (but also a significant determinant of the performance of the Slovak economy), there are significant differences (Figure 2). The development of wages in the Slovak Republic is, as compared to Germany, positive, growing steadily in the period of 2000-2019, with the regression model, the results of which are shown in the Table 2. Similarly, the development of wages in Germany, 
abstracted from the comparison with the Slovak Republic, has a positive trend which can only be supported by a statistically proved regression model (Table 3). The statistical evidence is significant.

Fig. 2 The development of average annual wages in the Slovak Republic and Germany (at current prices in $€$ )

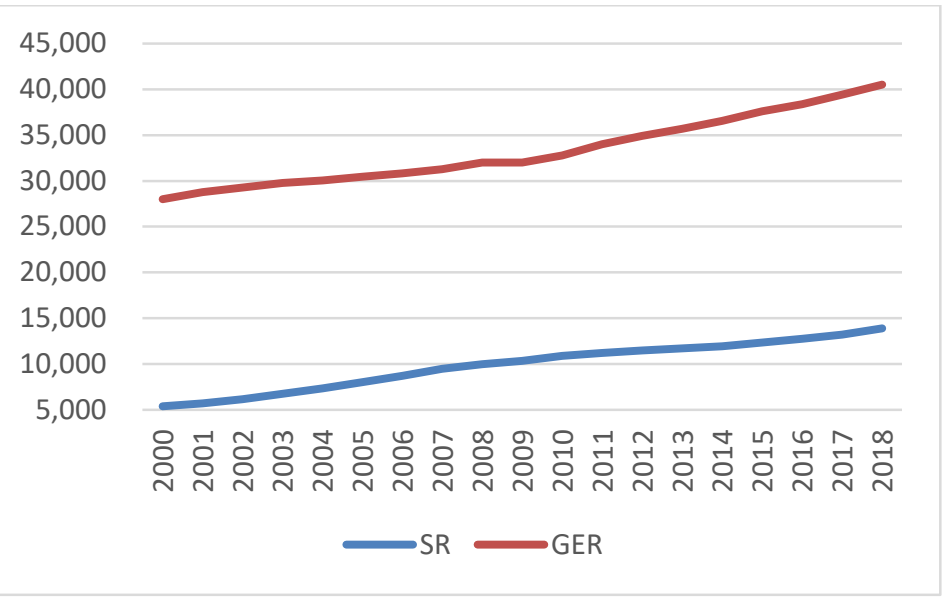

Source: Own processing based on the data of the OECD.

Tab. 2 Regression analysis results, modelling of annual wages development in the Slovak Republic

\begin{tabular}{|c|c|c|c|c|c|}
\hline \multirow[b]{2}{*}{ Model } & \multicolumn{2}{|c|}{ Unstandardized Coefficients } & \multirow{2}{*}{$\begin{array}{c}\text { Standardized } \\
\text { Coefficients } \\
\text { Beta }\end{array}$} & \multirow[b]{2}{*}{$\mathrm{T}$} & \multirow[b]{2}{*}{ Sig. } \\
\hline & B & Std. Error & & & \\
\hline 1 (Constant) & 5181.368 & 184.700 & & 28.053 & .000 \\
\hline Year & 467.553 & 16.199 & .990 & 28.863 & .000 \\
\hline
\end{tabular}

Notes: a. Dependent Variable: SR_OECD; based on the formula: $\mathrm{y}^{++}=5181.368^{++}+467.553^{++} \mathrm{x}$.

Source: Authors' calculation based on the analysed data.

Tab. 3 Regression analysis results, modelling of annual wages development in Germany

\begin{tabular}{|c|c|c|c|c|c|}
\hline \multirow[b]{2}{*}{ Model } & \multicolumn{2}{|c|}{ Unstandardized Coefficients } & Standardized & \multirow[b]{2}{*}{$\mathrm{T}$} & \multirow[b]{2}{*}{ Sig. } \\
\hline & B & Std. Error & Beta & & \\
\hline 1 (Constant) & 26598.000 & 349.609 & & 76.079 & .000 \\
\hline Year & 668.116 & 30.663 & .983 & 21.789 & .000 \\
\hline
\end{tabular}

Notes: a. Dependent Variable: GER_OECD; based on formula: $\mathrm{y}^{++}=26598.000^{++}+668.116^{++} \mathrm{x}$.

Source: Authors' calculation based on the analysed data. 
The model analyses show that the annual wages growth in Germany was approximately $€ 200$ higher than in the Slovak Republic in the analysed period (in absolute values). If taking into consideration a significantly different starting situation in the Slovak Republic and Germany, the often-heard question is set: Will there ever be the "German wages" in the Slovak Republic? The answer is unambiguous: Never. Of course, this is a kind of answer that will probably satisfy nobody, not the inhabitants at all. However, we shall keep in mind that it is a model ceteris paribus that captures a relatively short period. If this trend continued in both countries for a long period of time without any additional external and internal determinants affecting wages (except those already considered), the Slovak Republic would not able not reach the current German wages in 30 years. Index analysis could be an alternative analysis for better optimistic prospects. Its advantage is that the different starting bases are not so significant. The average wage growth in Germany during the reference period was 2.08\%, up to 5.42\% in the Slovak Republic. With the continuation of year-to-year increases for the following periods, Slovak salaries would be offset by German in 2052. Of course, it is debatable whether a high year-to-year increase (dominated by relatively low wage at the beginning of the analysed period) proves relevant Slovak ability to secure it in the next period. The answer could be found in the comparison of wages development with a change in labour productivity.

\subsection{Labour productivity in relation to wages development in the period of 2000-2019}

In the comparison of year-to-year changes in labour productivity, the high level of the Slovak Republic is evident. The change in labour productivity on a yearly basis in the Slovak Republic over the period is higher than in other surveyed countries. The fall to negative values was marked, and not only in the Slovak Republic, but for example, in Germany, or the EU as a whole, in 2009, which was linked to the upcoming global economic and financial crisis. A greater continual change might be seen in the Slovak Republic than in Germany (Figure 3). Therefore we decided to test the statistical significance of year-to-year changes in labour productivity in these countries in the period of 2000-2019 (due to the availability of the data sources). The results of the testing are presented in the Table 4.

Fig. 3 Labour productivity development in chosen countries (annual growth rate in percentage) 


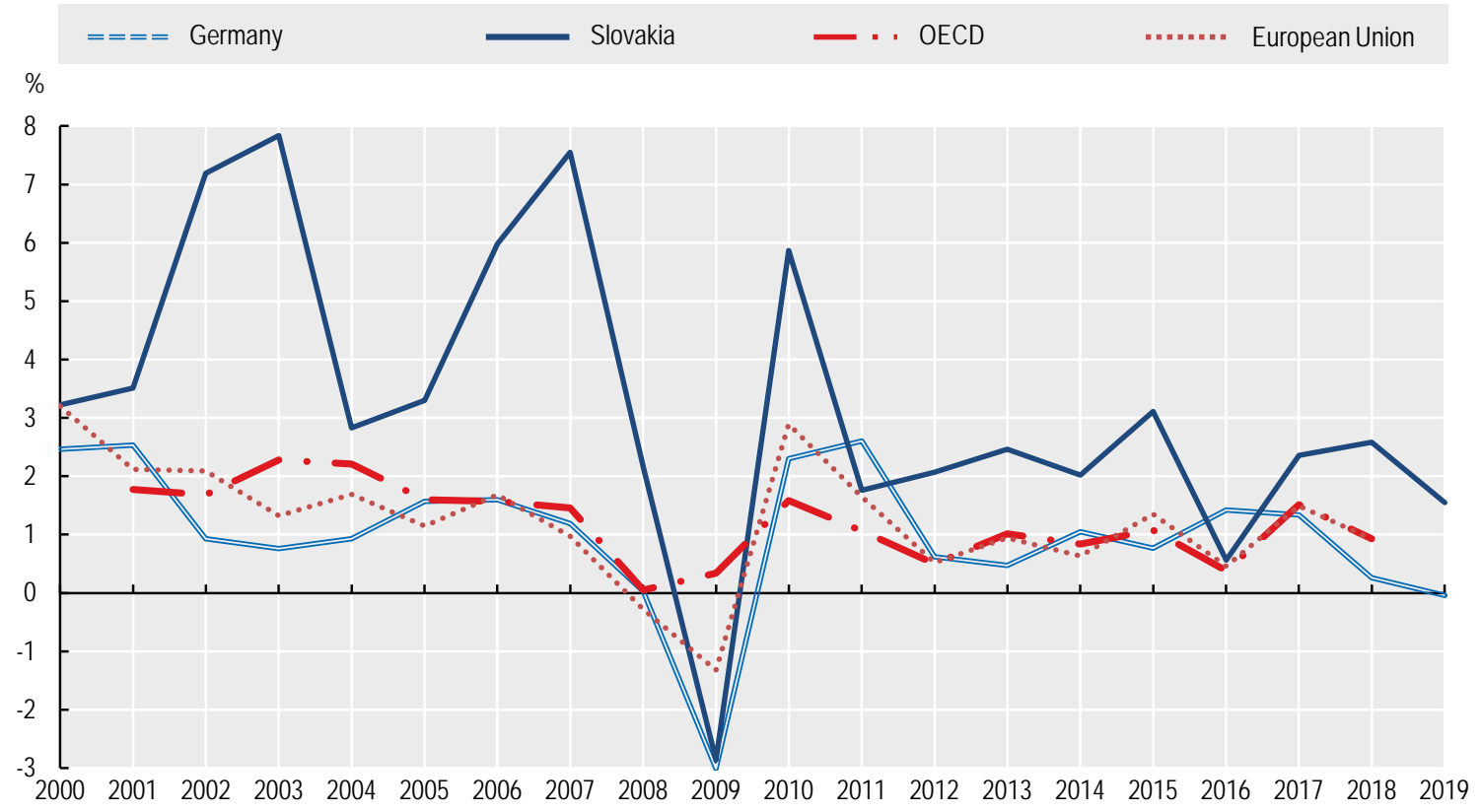

Note: Updated April $10^{\text {th }}$ 2020; the data of 28 countries of the EU and OECD from 2020 are not available.

Source: Own processing based on the data of the OECD.

Tab. 4 Test results, t-tests, analysis of labour productivity changes in the Slovak Republic and Germany

\begin{tabular}{|c|c|c|c|c|c|c|c|c|c|c|}
\hline & \multicolumn{2}{|c|}{$\begin{array}{l}\text { Levene's Test } \\
\text { for Equality } \\
\text { of Variances }\end{array}$} & \multicolumn{7}{|c|}{ t-test for Equality of Means } \\
\hline & & \multirow[b]{2}{*}{$\mathrm{F}$} & \multirow[b]{2}{*}{ Sig. } & \multirow[b]{2}{*}{$\mathrm{t}$} & \multirow[b]{2}{*}{$\mathrm{df}$} & \multirow{2}{*}{$\begin{array}{c}\text { Sig. } \\
(2- \\
\text { tailed) }\end{array}$} & \multirow{2}{*}{$\begin{array}{c}\text { Mean } \\
\text { Difference }\end{array}$} & \multirow{2}{*}{$\begin{array}{l}\text { Std. Error } \\
\text { Difference }\end{array}$} & \multicolumn{2}{|c|}{ 95\% Confidence } \\
\hline & & & & & & & & & Lower & Upper \\
\hline \multirow{2}{*}{$\begin{array}{l}\text { work } \\
\text { productivity }\end{array}$} & $\begin{array}{l}\text { Equal } \\
\text { variances } \\
\text { assumed }\end{array}$ & \multirow[t]{2}{*}{5.520} & \multirow[t]{2}{*}{.024} & \multirow[t]{2}{*}{3.566} & \multirow[t]{2}{*}{38} & \multirow[t]{2}{*}{.001 } & \multirow[t]{2}{*}{2.27350} & \multirow[t]{2}{*}{.63753} & \multirow[t]{2}{*}{98289} & \multirow[t]{2}{*}{3.56411} \\
\hline & $\begin{array}{l}\text { Equal } \\
\text { variances } \\
\text { not } \\
\text { assumed }\end{array}$ & & & & & & & & & \\
\hline
\end{tabular}

Source: Authors' calculation based on the analysed data.

Based on the results of testing, it is clear that there is a statistically significant difference between the year-to-year change in labour productivity in the Slovak Republic and Germany over the monitored period. The average difference between changes in labour productivity is $2.27 \%$ in favour of the Slovak Republic. Higher average annual increase in labour productivity in the Slovak 
Republic led to significant cumulative differences over the whole analysed period (labour productivity in Germany grew by $18.7 \%$, while in the Slovak Republic, it grew by $82.7 \%$ ).

Fig. 4 Cumulative labour productivity change (the year 2000 refers to $100 \%$ )

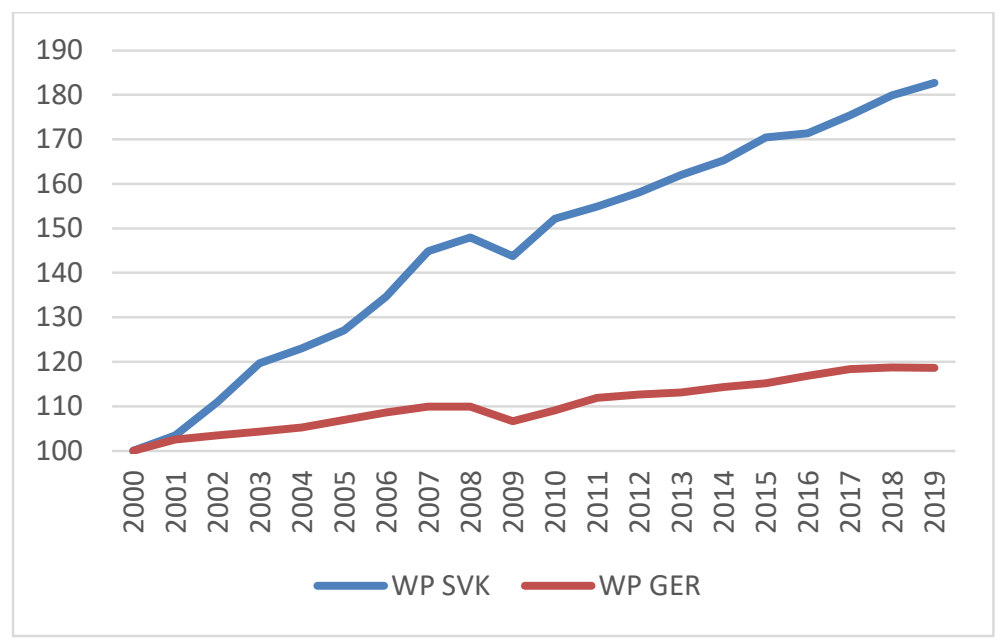

Source: Own processing based on the data of the OECD.

The question is to what extent has the increase in labour productivity been projected into the rise in wages? The increase in wages for a comparable period (2000-2019) is even more dramatic - while in Germany the wages grew by $44.8 \%$, the number in the Slovak Republic raised up to $157 \%$ (Figure 5). However, in this calculation the authors do not take the data of wages growth in OECD in 2019 into consideration, as these were not available at the time of study finalization.

Fig. 5 Cumulative change of gross wages (the year 2000 refers to 100\%)

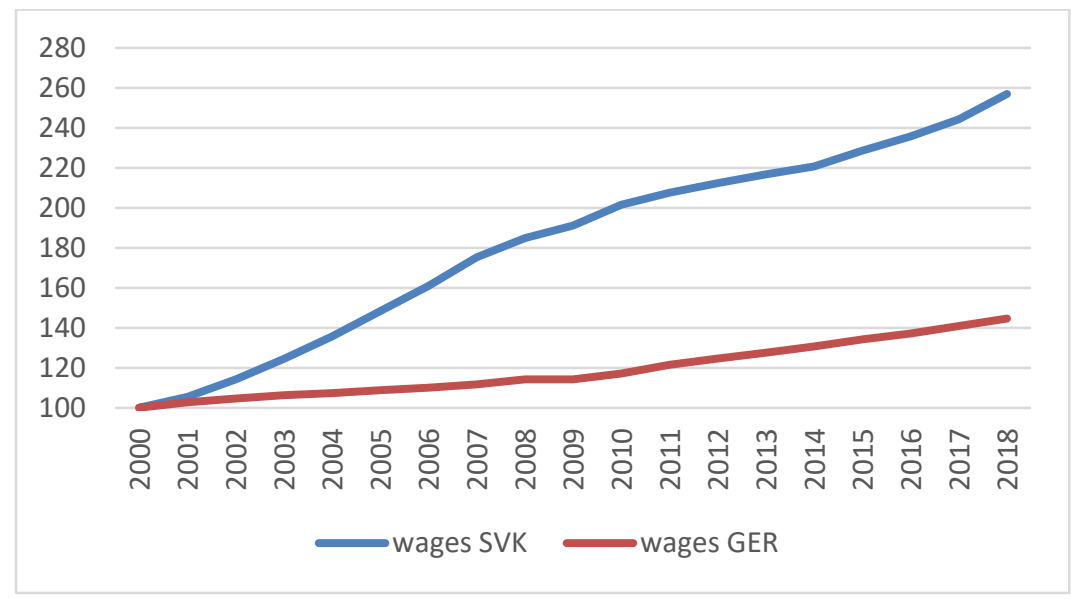

Source: Own processing based on the data of the OECD.

Here we come to the main point of discussion: To what extent is this wage increase, especially in 
the Slovak Republic, sustainable? The question is not only economic but also other dimensions must be considered: political, legislative, social, ideological, cultural, etc. It is absolutely legitimate to meet the expectations of labour (basically presented by working inhabitants) to try to bring living standards closer to the quality life level of developed countries, especially if there are no significant barriers to stronger interactions between them (Grdinić et al., 2017).

\subsection{Correlations and development evaluation - the Slovak and German example in relation to the EMU participation}

However, it is highly desirable to identify to what extent this dramatic wage growth is underpinned by labour productivity growth. We monitored the relationship between the given variables separately in Germany and in the Slovak Republic. As it was not possible to reject the hypotheses about the normality of the distribution of files (Kolmogorov-Smirnov test) within the analysed file of data corresponding to Germany (annual growth in productivity, annual growth in wages), we therefore look at the relationship between wages change and the change in labour productivity in each analysed year separately and, alternatively, with the annual delay in changing of wages to the change record in labour productivity. In the second case, we assume that the change in wages should respond to the change in labour productivity with a certain delay (due to the imperfection of the market), in our case by one year. When we analyse the relationship without an annual shift, we get results that are statistically significant. Thus, we can say that there is a statistically significant relationship between the annual change in labour productivity and the annual change of wages. If we take the correlation coefficient value into consideration, we may speak of a medium strong relationship.

Tab. 5 Correlation analysis results, relationship between annual change in labour productivity and annual change in wages in Germany (2000-2018)

\begin{tabular}{|l|l|r|r|}
\hline \multicolumn{2}{|c|}{} & GER_WP_change & GER_wages_change \\
\hline GER_WP_change & Pearson Correlation & 1 & $.594^{* *}$ \\
& Sig. (2-tailed) & 18 & .009 \\
& $\mathrm{~N}$ & $.594^{* *}$ & 18 \\
\hline GER_wages_change & Pearson Correlation & .009 & 1 \\
& Sig. (2-tailed) & 18 & 18 \\
\hline
\end{tabular}

Note: ${ }^{* *}$ Correlation is significant at the 0.01 level (2-tailed).

Source: Authors' calculation based on the analysed data. 
When analysing the relationship with an annual delay, we get even less reliable and insignificant results. However, as the data of 2019 related to wages development were not available, we analysed both labour productivity and wages changes in the period of 2000 to 2018 in these partial calculations.

Tab. 6 Correlation analysis results, relationship between annual change in labour productivity and annual change in wages in Germany, the annual shift in wages (2000-2018)

\begin{tabular}{|l|l|r|r|}
\hline \multicolumn{2}{|c|}{} & GER_WP_change & GER_wages_change \\
\hline GER_WP_change & Pearson Correlation & 1 & .177 \\
& Sig. (2-tailed) & 17 & .497 \\
& N & .177 & 17 \\
\hline GER_wages_change & Pearson Correlation & .497 & 1 \\
& Sig. (2-tailed) & 17 & 17 \\
& N & 17 & \\
\end{tabular}

Source: Authors' calculation based on the analysed data.

The analyses show two statistically different reliable results. While we observe a statistically significant correlation in monitoring the relationship between labour productivity and wages in the standard year, we do not see this correlation in the event of a one-year delay in labour productivity wages. On the basis of the partial analyses results, it is much more appropriate to monitor the relationship between the change in labour productivity and the change in wages in the analysed year, not with an annual delay. In the case of the analysis of the correlation between the growth of labour productivity and wages growth in the Slovak Republic, we performed the analysis by parametric methods, as the parameters analysed by the Kolmogorov-Smirnov test of normality did not lead to the rejection of the hypothesis about the normal distribution of variables (Table 7). In the case of an annual change in wage growth including the annual delay in the change in labour productivity, the following results were achieved (Table 8).

Tab. 7 Correlation analysis results, relationship between change in annual labour productivity and annual change in wages in the Slovak Republic (2000-2018)

\begin{tabular}{|l|l|r|r|}
\hline \multicolumn{2}{|c|}{} & SVK_WP_change & SVK_wages_change \\
\hline SVK_WP_change & Pearson Correlation & 1 & $.693^{* *}$ \\
& Sig. (2-tailed) & 18 & .001 \\
& $\mathrm{~N}$ & $.693^{* *}$ & 18 \\
\hline SVK_wages_change & Pearson Correlation & .001 & 1 \\
& Sig. (2-tailed) & 18 & 18 \\
& $\mathrm{~N}$ & & \\
\end{tabular}

Note: ** Correlation is significant at the 0.01 level (2-tailed). 
Source: Authors' calculation based on the analysed data.

Tab. 8 Correlation analysis results, relationship between annual change in labour productivity and annual change in wages in the Slovak Republic, the annual shift in wages (2000-2018)

\begin{tabular}{|l|l|r|r|}
\hline \multicolumn{2}{|c|}{} & SVK_WP_change & SVK_wages_change \\
\hline SVK_WP_change & Pearson Correlation & 1 & .443 \\
& Sig. (2-tailed) & 17 & .075 \\
& $\mathrm{~N}$ & .443 & 17 \\
\hline SVK_wages_change & Pearson Correlation & .075 & 1 \\
& Sig. (2-tailed) & 17 & 17 \\
\hline
\end{tabular}

Source: Authors' calculation based on the analysed data.

On the basis of the analyses performed, we may state that the wage growth in the Slovak Republic is strongly related to the increase in labour productivity. The deceleration of wage changes in comparison to the changes in labour productivity by one year leads to a significant deterioration of the coherence of evidence. Thus, labour productivity strongly determines wages and all changes in labour productivity affect the changes in wages development. However, we should look at the problem differently, the other question is what might imply a change in labour productivity, in other words to what extent are we able to quantify labour productivity determinants? In the literature, we can meet different classifications of labour productivity growth factors (Syverson 2011; Krauszová 2006; and others). Considering the context and the aim of the research, we analyse the most significant questionable determinant - the entrance of the country into the EMU.

Tab. 9 Testing analysis results, t-tests, change in labour productivity analysis in the Slovak Republic taking into account the EMU entrance (2000-2019)

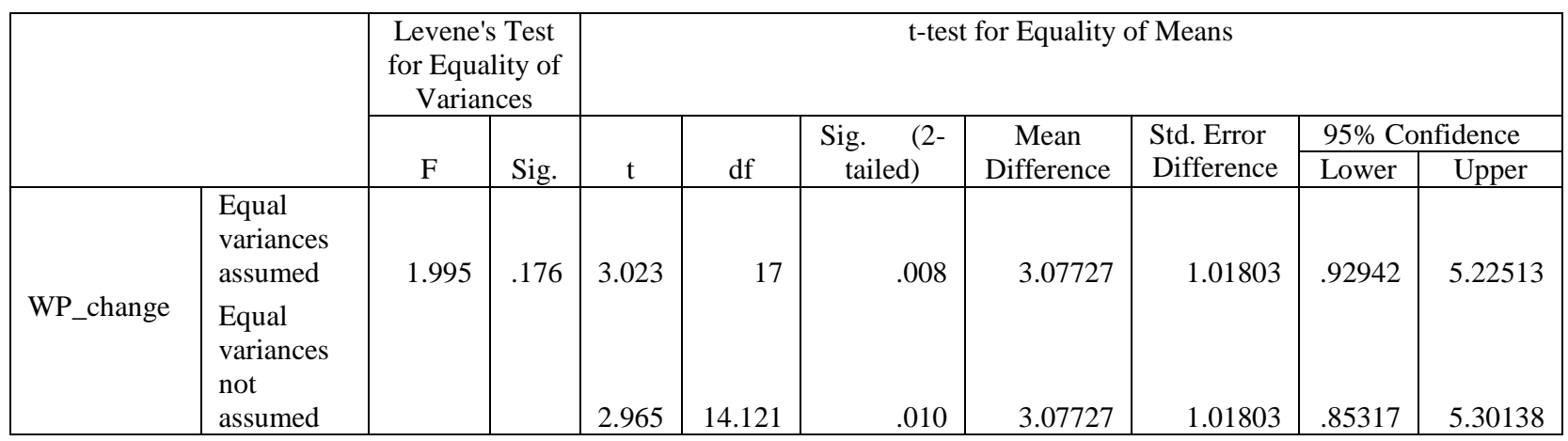

Source: Authors' calculation based on the analysed data. 
The results show that there are statistically significant differences between annual changes in labour productivity in the pre-accession and post-entry period. However, joining the EMU did not lead to higher labour productivity in the Slovak Republic. In the pre-accession period, labour productivity grew significantly faster by $3.077 \%$ (average growth of $5.05 \%$ in pre-accession and $1.97 \%$ in post-accession periods). This result though might be negated by the consequences of the crisis in 2009, which is actually the year of the Slovak entrance into the EMU. If we analysed the abstracted data from 2009 on, the results would be different (Table 10).

Tab. 10 Testing analysis results, t-test, analysis of changes in labour productivity in the Slovak Republic reflecting the entrance into the EMU (2000-2019) - excluding the data from 2009

\begin{tabular}{|c|c|c|c|c|c|c|c|c|c|c|}
\hline & \multicolumn{2}{|c|}{$\begin{array}{c}\text { Levene's } \\
\text { Test for } \\
\text { Equality of } \\
\text { Variances }\end{array}$} & \multicolumn{7}{|c|}{ t-test for Equality of Means } \\
\hline & & \multirow[b]{2}{*}{$\mathrm{F}$} & \multirow[b]{2}{*}{ Sig. } & \multirow[b]{2}{*}{$\mathrm{t}$} & \multirow[b]{2}{*}{$\mathrm{df}$} & \multirow{2}{*}{$\begin{array}{l}\text { Sig. }(2- \\
\text { tailed) }\end{array}$} & \multirow{2}{*}{$\begin{array}{c}\text { Mean } \\
\text { Difference }\end{array}$} & \multirow{2}{*}{$\begin{array}{l}\text { Std. Error } \\
\text { Difference }\end{array}$} & \multicolumn{2}{|c|}{ 95\% Confidence } \\
\hline & & & & & & & & & Lower & Upper \\
\hline \multirow[b]{2}{*}{ WP_change } & $\begin{array}{l}\text { Equal } \\
\text { variances } \\
\text { assumed }\end{array}$ & 8.556 & 010 & 2.932 & 16 & .010 & 2.59000 & .88331 & .71746 & 4.46254 \\
\hline & $\begin{array}{l}\text { Equal } \\
\text { variances } \\
\text { not } \\
\text { assumed }\end{array}$ & & & 2.710 & 10.817 & .018 & 2.59000 & .93512 & .52755 & 4.65245 \\
\hline
\end{tabular}

Source: Authors' calculation based on the analysed data.

The analysis led to limited values to allow the rejection of the concurrence of the set of variances, therefore we prefer to analyse the average value match of the samples of differing variances. The results indicate the existence of statistically significant differences in the average labour productivity values of pre-accession and post-accession periods. We may see that the higher average labour productivity was achieved in the pre-accession period. The higher value of average labour productivity growth in the pre-accession period was even achieved with the inclusion of the post-crisis year (2010) indicating a high labour productivity increase (after a drop in 2009). Consequently, it is not possible to accept conclusions that are so often popularly presented in public that the Slovak entry into the EMU led to an increase in labour productivity. Rather, we could conclude that it led to a more balanced growth (excluding the 2009 crisis year) by comparing the standard deviations of pre-accession and recession periods ( $2.337 \mathrm{vs.} 1.384)$. We come to the same 
conclusion when analysing the influence of the Slovak Republic's entry into the EMU on the wage dynamics differential (Table 11, Table 12).

Tab. 11 Pair-testing analysis results, t-tests, analysis of changes in wages in the Slovak Republic in the EMU pre-accession and post-accession period (2000-2018)

\begin{tabular}{|c|c|c|c|c|c|c|c|c|c|c|}
\hline & \multicolumn{2}{|c|}{$\begin{array}{l}\text { Levene's Test } \\
\text { for Equality } \\
\text { of Variances }\end{array}$} & \multicolumn{7}{|c|}{ t-test for Equality of Means } \\
\hline & & \multirow[b]{2}{*}{$\mathrm{F}$} & \multirow[b]{2}{*}{ Sig. } & \multirow[b]{2}{*}{$\mathrm{t}$} & \multirow[b]{2}{*}{ Df } & \multirow{2}{*}{$\begin{array}{l}\text { Sig. (2- } \\
\text { tailed) }\end{array}$} & \multirow{2}{*}{$\begin{array}{c}\text { Mean } \\
\text { Difference } \\
\end{array}$} & \multirow{2}{*}{$\begin{array}{l}\text { Std. Error } \\
\text { Difference }\end{array}$} & \multicolumn{2}{|c|}{ 95\% Confidence } \\
\hline & & & & & & & & & Lower & Upper \\
\hline \multirow{2}{*}{$\begin{array}{l}\text { wages_ } \\
\text { change }\end{array}$} & $\begin{array}{l}\text { Equal } \\
\text { variances } \\
\text { assumed }\end{array}$ & 0.705 & .413 & 7.029 & 16 & .000 & 4.6375 & .6598 & 3.2389 & 6.0361 \\
\hline & $\begin{array}{l}\text { Equal } \\
\text { variances not } \\
\text { assumed }\end{array}$ & & & 6.831 & 13.088 & .000 & 4.6375 & .6598 & 3.1719 & 6.1031 \\
\hline
\end{tabular}

Source: Authors' calculation based on the analysed data.

Tab. 12 Pair-testing analysis results, t-tests, analysis of changes in wages in the Slovak Republic in the EMU pre-accession and post-accession period (2000-2018) - excluding 2009

\begin{tabular}{|c|c|c|c|c|c|c|c|c|c|c|}
\hline & \multicolumn{2}{|c|}{$\begin{array}{c}\text { Levene's } \\
\text { Test for } \\
\text { Equality of } \\
\text { Variances }\end{array}$} & \multicolumn{7}{|c|}{ t-test for Equality of Means } \\
\hline & & \multirow[b]{2}{*}{$\mathrm{F}$} & \multirow[b]{2}{*}{ Sig. } & \multirow[b]{2}{*}{$\mathrm{t}$} & \multirow[b]{2}{*}{ Df } & \multirow{2}{*}{$\begin{array}{l}\text { Sig. (2- } \\
\text { tailed) }\end{array}$} & \multirow{2}{*}{$\begin{array}{c}\text { Mean } \\
\text { Difference }\end{array}$} & \multirow{2}{*}{$\begin{array}{l}\text { Std. Error } \\
\text { Difference }\end{array}$} & \multicolumn{2}{|c|}{ 95\% Confidence } \\
\hline & & & & & & & & & Lower & Upper \\
\hline \multirow{2}{*}{$\begin{array}{l}\text { wages_ } \\
\text { change }\end{array}$} & $\begin{array}{l}\text { Equal } \\
\text { variances } \\
\text { assumed }\end{array}$ & .328 & .575 & 6.652 & 15 & .000 & 4.6431 & .6980 & 3.1553 & 6.1308 \\
\hline & $\begin{array}{l}\text { Equal } \\
\text { variances not } \\
\text { assumed }\end{array}$ & & & 6.575 & 13.696 & .000 & 4.6431 & .7061 & 3.1254 & 6.1607 \\
\hline
\end{tabular}

Source: Authors' calculation based on the analysed data.

There is no significant impact on the results of the analysis if including (or excluding) the crisis year 2009 into it. Similarly, to the average change in labour productivity, even in the change of wages, statistically significant differences can be noted in favour of the pre-accession period (Jenčová et al., 2015). The average annual increase in pre-accession and post-accession periods proves statistically significant differences. In the pre-accession period, the wages grew by about nearly 5\% faster than in the post-accession period. Similarly, to the changes in labour productivity, there is a smaller annual variability in the post-accession period after 2009 (standard deviation of 
1.573 before the EMU entrance compared to 1.305 after 2009). However, the Slovak economy is very heterogeneous. To evaluate the wages, or the labour productivity, only from a macroeconomic point of view does not have to objectively correspond with the performance of individual industries, with the long-term sustainability of wage policies within the economic area. The development of nominal wages in the economy sectors over the period under review is broadly increasing, but there are significant sectorial disparities over time that might be analysed in further researches.

\section{Conclusion}

In the research, we focused on the analysis of pre-coronavirus changes in labour productivity and changes in wages (as selected economic criteria) from multiple partial points of view. It is necessary to realize, that over the past decade, the Slovak Republic has witnessed a dramatic increase in wages in the national economy, which may cause doubt about the healthiness of its development. However, in comparison with labour productivity, we can conclude that this increase in wages is of similar trend to that of the increase in labour productivity. Though, during the analysed period, the wages in the Slovak Republic grew cumulatively more than labour productivity, it should be remembered that this analysis was performed on the basis of the year 2000 as a starting point, in which the level of both wages and labour productivity was $100 \%$. Previous years (up to 2000) marked an increase in unemployment and lower wage pressures in the Slovak economy, which could lead to the creation of a certain internal wage reserve, which could have been gradually released in the next years. On the contrary, the significant drop in unemployment in the next period led to a higher demand for an employee, accompanied by an increase in wages. On the basis of the analyses performed, we state that the wages development in the national economy cannot be described as unsustainable. The results of analyses prove the relationship between labour productivity and wages, where the statistical reliability between the growth of labour productivity and the growth of wages with a high degree of tightness of relationships was proved, as well as a gradual decline in wages growth. The tightness of the relationship between these indicators as well as the statistical reliability was quite of similar statistical significance for both the Slovak data file and the German one. However, a relatively short (19 years) comparative period should be kept in mind. Both compared countries experience 
a great economic challenge now, probably caused by the coronavirus crisis - however, the question is, due to the research results, was this crisis not predictable? It the coronavirus issue not just accelerating phenomenon? The Slovak example clearly presents a warning case-study model.

In both countries (Germany was chosen as an example of dynamic progressive European country), the growth of wages over the analysed period was accompanied by a growth in labour productivity. This relationship is statistically significant as it is shown by the high intensity of the relationship of the given variables. Therefore, over the analysed period it is possible to argue that the recorded wage growth in the Slovak economy is "natural and healthy", for it may find its economic justification in the growth of labour productivity. Even in the case of the Slovak Republic, even in the case of Germany, the change in wages is the result of a change in labour productivity. This relationship has only been proved if the annual changes in wages and labour productivity have been taken into consideration within the research. If we expand the research analyses of the assumption that wage growth is copying the growth of labour productivity with a certain distance (in the study case referred to one year), the relationship between the change in wages and the change in labour productivity will not be confirmed. This conclusion refers to both Slovak and German study case.

If we analyse the impact of the Slovak Republic's entrance into the EMU on the change in wages or labour productivity (the EMU entrance is viewed as a political act with possible subsequent economic benefits), we did not prove any positive impact on wages or labour productivity in the post-accession period. Of course, it is just a review of the status and development of two periods, not a complex analysis of the impact of the EMU accession. It is possible that a later entry would lead to a lower increase in labour productivity or wages, therefore the partial conclusions on the impact of the Slovak entrance into the EMU in terms of wage changes or labour productivity is a simple evaluation of changes in the performance of the two periods.

But what if the overall process is integrated with an immediate pandemic that brings about a different functioning and even a halt to the economy? Retail stores, hotels, bars and restaurants have been closed or restricted to delivery, a growing group of service providers and retailers are losing their jobs, sports events such as the NBA and the Olympic Games have been suspended and postponed, the pandemic shock is rising. While the first and most important aspect of the epidemic is and always remains the loss of human life, the spread of the virus can also have important 
consequences for national or regional economies. Evidence from various studies suggests (e.g. Chakraborty \& Maity 2020; Açikgöz \& Günay 2020; Mesa et al. 2020; Zhang et al., 2020) that the epidemic has an impact on the country's economy through several channels, including the health, transport, agriculture and tourism sectors, the economy deteriorates at least because of government health constraints. At the same time, trade with other countries can be affected by safeguard measures, which, in the case of open economies and the interconnection of modern economies, logically implies a negative impact on international supply chains, as factory shutdowns and quarantine measures are spreading worldwide. Moreover, rapid urbanization, increasing international travel and climate change make the outbreak of the epidemic a global phenomenon and not just a local phenomenon, indicating the need to take the necessary measures to combat this threat in all countries.

However, the results of the research show that even in the case of such significant threat as pandemic Covide-19 undoubtedly is, it is in the case of such adjustment of the economy explicitly only accelerated crisis, not an unpredictable state.

\section{References}

1. Açikgöz. Ö. \& Günay. A. (2020). The early impact of the Covid-19 pandemic on the global and Turkish economy. Turkish Journal of Medical Sciences, 50, pp. 520-526.

2. Balcar, J. \& Gottvald, J. (2016). Wage Determinants and Economic Crisis 2008-2014: Evidence from Czech Republic. Ekonomicky casopis, 64(1), pp. 3-21.

3. Čajka, P. \& Abrhám, J. (2019). Regional aspects of V4 countries’ economic development over a membership period of 15 years in the european union. Slovak Journal of Political Sciences, 19(1), pp. 89-10, doi: 10.34135/sjps.190105.

4. Chakraborty, I. \& Maity, P. (2020). COVID-19 outbreak: Migration, effects on society, global environment and prevention. Science of the Total Environment, 728, pp. 1-7.

5. Charaia, V., Chochia, A. \& Lashkhi, M. (2020). The impact of fdi on Economic development: The case of Georgia. TalTech Journal of European Studies, 10(2), pp. 96116, doi: 10.1515/bjes-2020-0017. 
6. Dudic, B., Dudic, Z., Pejanovic, R., Skataric, G., Saxunova, D. \& Peracek, T. (2020). The rural policy of Slovakia after joining the EU. Agriculture and Forestry, 66 (3), pp. 33-51. doi: 10.17707/AgricultForest.66.3.04.

7. Eurostat. (2016). Eurostat statistical database. [online] European Commission. Available at: http://ec.europa.eu/eurostat/data/database [Accessed 2020-04-04].

8. Fehr, E. \& Goette, L. (2005). Robustness and Real Consequences of Nominal Wage Rigidity. Journal of Monetary Economics, 52(4), pp. 779-804.

9. Finkelstein, SA. \& González. GA. (2017). Credit market imperfections, labor markets, and leverage dynamics in emerging economies. Journal of International Money and Finance, 78(C), pp. 44-63.

10. Gault, F. (2018). Defining and measuring innovation in all sectors of the economy. Research policy, 47(3), pp. 617-622.

11. Giannone, D., Reichlin, L. \& Small, D. (2008). Nowcasting: The Real-time Informational Content of Macroeconomic Data. Journal of Monetary Economics, 55(4), pp. 665-676.

12. Goerree, JK. \& Lindsay, L. (2016). Market Design and the Stability of General Equilibrium. Journal of Economy Theory, 165, pp. 37-68.

13. Grdiniċ. M, Drezgic̀, S, \& Blažic, H. (2017). An Empirical Analysis of the Relationship between Tax Structures and Economic Growth in CEE Countries. Ekonomicky casopis, 65(5), pp. 426-447.

14. Hajduova, Z., Peracek, T., Coronicova Hurajova, J. \& Bruothova, J. (2021). Determinants of innovativeness of Slovak SMEs. Problems and Perspectives in Management, 19(1), pp. 198-208, doi:10.21511/ppm.19(1).2021.17.

15. Chochia, A. \& Kerikmäe, T. (2018). Digital Single Market as an Element in EU-Georgian Cooperation. Baltic Journal of European Studies, 8(2), pp. 3-6, doi: 10.1515/bjes-20180012.

16. Jenčová, S., Litavcová, E., Kotulič, R. \& Vavrek, B. (2015). Phenomenon of poverty and economic inequality in the Slovak republic. Procedia Economics and Finance, 26, pp. 737741, doi:10.1016/S2212-5671(15)00832-1.

17. Kajanová, J., Mucha, B., Brestovanská, P. \& Peráček, T. (2018). Simple company on shares as startup support tool. Acta Universitatis Agriculturae et Silviculturae Mendelianae Brunensis, 66(6), pp. 1601-1611, doi:10.11118/actaun20186606160. 
18. Kovačiková, K. \& Jančovičová, M. (2017). Vývoj priemerných miezd na trhu práce v Slovenskej republike. [online] VSFS, Praha. Available at: https://www.vsfs.cz/prilohy/konference/kd_2017_kovacikova_jancovicova.pdf [Accessed 2019-07-14].

19. Lim, WM. (2017). Inside the sustainable consumption theoretical toolbox: Critical concepts for sustainability, consumption, and marketing. Journal of Business Research, 78, pp. 69-8, doi: 10.1016/j.jbusres.2017.05.001.

20. Lubyová, M. \& Štefánik, M. (2016). Labour Market in Slovakia 2017+. SAV, Bratislava.

21. Martino, R. (2015). Convergence and growth. Labour productivity dynamics in the European Union. Journal of Macroeconomics, 46(C), pp.186-200.

22. Mesa, V., Cristina, F., Oscar, H., Gómez, R. \& Carlos, AT. (2020). COVID-19: The forgotten priorities of the pandemic. Maturitas, 136, pp.38-41.

23. Mihálik, J., Horváth, P. \& Švikruha, M. (2019). Give me liberty or give me money: the fiscal decentralization and autonomy of regional governance in Slovakia. European Journal of Government and Economics, 8(1), pp. 96-109, doi: 10.17979/ejge.2019.8.1.4573

24. Mucha, B., Brestovanská, P. \& Peráček, T. (2018). Using the correct sampling method as a prerequisite for a successful financial audit. Proceedings of the 31st International Business Information Management Association Conference, IBIMA 2018: Innovation Management and Education Excellence through Vision 2020, pp. 3503-3511.

25. Novackova, D. \& Peracek, T. (2021). The Common European Investment Policy and Its Perspectives in the Context of the Achmea Case Law. TalTech Journal of European Studies, 11(1), pp. 153-169, doi: 10.2478/bjes-2021-0010.

26. Novosák, J., Novosáková, J., Hájek, O. \& Górska-Szymcak, J. (2017). The geography of new business formation in the Czech Republic: a cross section analysis (2003-2014). Human geographies, 11(2), pp.169-180.

27. OECD Manual. [online] OECD, Bratislava. Available at: www.oecd.org/std/productivitystats [Accessed 2019-03-27].

28. Peráček, T. (2021). Flexibility of creating and changing employment in the options of the Slovak Labor Code. Problems and Perspectives in Management, 19(3), pp. 373-382. doi:10.21511/ppm.19(3).2021.30. 
29. Psychogios, A., Szamosi, LT., Prouska, R. \& Brewster, C. (2019). Varieties of crisis and working conditions: A comparative study between Greece and Serbia. European Journal of Industrial Relations. 26(1), pp. 91-106, doi:10.1177/0959680119837101.

30. Rusnák, M. (2016). Nowcasting Czech GDP in real time. Economic Modelling, 54(C), pp. 26-39, doi:10.1016/j.econmod.2015.12.010.

31. Sinikačová, M. \& Gavurová, B. (2017). Single Monetary Policy versus Macroeconomic Fundamentals in Slovakia. Ekonomický časopis, 65(2), pp. 158-172.

32. Srebalová, M., Vojtech, F. (2021). SME Development in the Visegrad Area. Eurasian Studies in Business and Economics, 17, pp. 269-281, doi: 10.1007/978-3-030-65147-3_19.

33. STATDAT. Average monthly wages in selected branches by months. [online] STATDAT, Bratislava. Available at: http://datacube.statistics.sk/\#!/view/en/VBD_ INTERN/pr0201ms/Average\%20monthly\%20wages\%20in\%20selected\%20branches\%20 by\%20months\%20\%5Bpr0201ms\%5D [Accessed 2019-07-02].

34. Štatistický úrad Slovenskej republiky. [online] SUSR, Bratislava. Available at: http://www.statistics.sk/pls/elisw/metainfo.explorer?obj=40\&cmd=go\&s=1002\&sso=2\& so=15 [Accessed 2019-07-27].

35. Šubová, N., Mura, L. \& Buleca, J. (2021). Determinants of household financial vulnerability: Evidence from selected eu countries. E a M: Ekonomie a Management, 24(3), pp. 186-207, doi: 10.15240/TUL/001/2021-3-011.

36. Syverson, Ch. (2011). What determines productivity? Journal of Economic Literature, 49(2), pp. 326-365.

37. Szeiner, Z., Mura, L., Horbulák, Z., Roberson, M. \& Poór, J. (2020). Management consulting trends in slovakia in the light of global and regional tendencies. Journal of Eastern European and Central Asian Research, 7(2), pp. 191-204, doi: 10.15549/jeecar.v7i2.390https://forms.office.com/Pages/ResponsePage.aspx?id=jUcxznp u50yGcKW51RiE-

X_zV2mjfupIj7N_amxJPARUQVhTRUdaS1c0VTJUTE1UQIVHRFcxMjFSSy4u.

38. Terem, P., Čajka, P. \& Rýsová, L. ～(2015). Europe 2020 strategy: Evaluation, implementation, and prognoses for the Slovak Republic. Economics and Sociology, 8(2), pp. 154-171, doi: 10.14254/2071-789X.2015/8-2/12. 
39. Testing, mathematics modeling. [online] NIST Gaithersburg Available at: https://www.nist.gov/itl/itl-industry-impacts [Accessed 2019-08-12].

40. Tijdens, K., Van Klaveren, M., Bispinck, R., Dribbusch, H. \& Öz, F. (2014). Wage and workforce adjustments in the economic crisis in Germany and the Netherlands. European Journal of Industrial Relations, 20(2), pp. 165 -183. doi:10.1177/0959680113516181.

41. Vacok J., Srebalova, M., Horvath, M., Vojtech F. \& Filip, S. (2020). Legal obstacles to freedom to conduct a business: experience of the Slovak Republic, Entrepreneurship and Sustainability Issues, 7(4), pp. 3385-3394, doi: 10.9770/jesi.2020.7.4(53).

42. Vilcekova, L., Peracek, T., \& Strazovska, L. (2020). Selected problems of family business: A case study from Slovakia. Acta Polytechnica Hungarica, 17 (7), pp. 145-162. doi: 10.12700/APH.17.7.2020.7.8 .

43. Wefersová, J. \& Nováčková, D. (2021). Use of Digital Technologies in Business in Slovakia. Studies in Systems, Decision and Control, 376, pp. 335-355, doi: 10.1007/9783-030-76632-0_12.

44. Zhang, D., Hu, M., \& Ji, Q. (2020). Financial markets under the global pandemic of COVID-19. Finance research letters, 36, 101528. https://doi.org/10.1016/j.frl.2020 .101528.

45. Žofčinová, V. \& Hrabovská, Z. (2019). Problems of unemployment through the employment policy in the labour market: The case of the Slovak Republic and the Czech Republic. Public Administration Issues, (5), pp. 103-119, doi: 10.17323/1999-5431-20190-5-103-11.9. 